\title{
Contribution to the knowledge of the Moroccan mountain vegetation
}

\author{
A. M. ROMO \\ Botanical Institute of Barcelona (CSIC-ICUB), Psg. del Migdia s/n, Parc de Montjuïc, 08038 Barcelona, Spain. \\ E-mail: a.romo@ibb.csic.es
}

Received 2 April 2009; Accepted 29 July 2009

\begin{abstract}
Different types of plant communities, till now undetected in Morocco, are here described using the phytosociological method. The following new subassociations and associations are proposed: Anthyllido polycephalae-Stachydetum fontqueri subass. quercetosum rotundifoliae is a machia from the Northern Rif Mountains; Genisto anglicae-Ericetum ciliaris subsass. pinguiculetosum lusitanicae is a heathland from the Bou Hassim range in the Western Rif; Cephalario maroccanae-Inuletum maletii is a megaphorbic community from the Middle Atlas; Bellis caerulescendis-Heracletum sphondyllii is a megaphorbic community from the High Atlas; Arenario armerinae-Sideritetum matris-filiae is a high mountain grassland from the Tichchoukt range in the Middle Atlas.

New data are given for the syntaxa already described but with the distribution, variability and ecology not well known. This is the case of the following associations: Polysticho setiferi-Prunetum lusitanicae, a riverine woodland from the W Rif Mountains; Primulo acaulis-Betuletum celtibericae, a birch woodland from the C Rif and Astragaletum numidico-maroccani a high mediterranean mountain plant community from the Western Rif.
\end{abstract}

As a conclusion, the vegetation of the peculiar habitats that occur in reduced areas is only partially known.

Key words: Atlas Mountains; Morocco; phytosociology; plant communities; Rif Mountains; vegetation.

\section{Resumen}

Contribución al conocimiento de la vegetación de las montañas marroquíes.- Se describe con la metodología fitosociológica diferentes tipos de comunidades vegetales, no detectadas hasta el presente en Marruecos. Se proponen las siguientes nuevas asociaciones y subasociaciones: Anthyllido polycephalae-Stachydetum fontqueri subass. quercetosum rotundifoliae corresponde a una maquia de las montañas septentrionales del Rif; Genisto anglicae-Ericetum ciliaris subsass. pinguiculetosum lusitanicae es un brezal del macizo de Bou Hassim en el Rif occidental; Cephalario maroccanaeInuletum maletii es una formación de megaforbios del Atlas Medio; Bellis caerulescendis-Heracletum sphondyllii es una formación de megaforbios del Gran Atlas; Arenario armerinae-Sideritetum matris-filiae es un pastizal de alta montaña mediterránea del macizo de Tichchoukt en el Atlas Medio.

Se aportan nuevos datos para otros sintáxones ya descritos pero con la distribución, variabilidad y ecología poco conocidas. Este es el caso de las asociaciones siguientes: Polysticho setiferi-Prunetum lusitanicae, bosquecillo ripario de las montañas del Rif occidental y central; Primulo acaulis-Betuletum celtibericae, corresponde a un bosque de abedules del Rif central, y Astragaletum numidico-maroccani es una comunidad de caméfitos de alta montaña mediterránea conocida hasta el presente del Rif occidental.

Como conclusión se puede aseverar que la vegetación de los hábitats que ocupan áreas reducidas en las montañas marroquíes es conocida de forma parcial.

Palabras clave: comunidades de plantas; fitosociología; Marruecos; montañas del Atlas; montañas del Rif; vegetación. 


\section{INTRODUCTION}

The decline of phytosociological studies, as insinuated by Fennane (2003), in Morocco, is in direct contrast with the progress being made in the field of vascular plant study. That this is the case is clearly demonstrated by recent works of a synthetic nature dealing with the native NW African flora. Some of these cover the whole territory (Fennane et al., 1999; 2005; 2007), while others deal with extensive territories (Valdés et al., 2002).

This progress in our knowledge of the flora should lead to a new "age of prosperity" for studies in the field of plant communities. With this in light, we have been able to order and detail more of our field data and have consequently diagnosed the floristic elements conserved in the collected material. The critical taxa of our relevés are supported by herbarium sheets that can be consulted in herbarium BC. All this is fruit of several expeditions made in the Maghreb (North West Africa) from 1985 up to the present day. The field data were annotated following the Braun-Blanquet phytosociological method (Braun-Blanquet, 1977). The block corresponding to rupicolous communities made up part of a recent publication (Romo, 2008).

Within Morocco, the Straights area (Galán de Mera, 1993; Deil, 1994, 1997) and the Central Rif (Deil, 1984) have received more attention from the phytosociological point of view, and these regions have been studied quite thoroughly. In contrast, vegetation studies have been less intense in the Western Rif, Eastern Rif and in certain habitats of the Atlas mountains.

\section{MATERIALS AND METHODS}

Throughout the process of our botanical explorations of Morocco, a number of relevés in accordance with the phytosociological methodology (BraunBlanquet, 1977; Mueller-Dombois \& Ellenberg, 1974; Dierschke, 1994) were elaborated. In these relevés the data of the studied stations are reordered in the standard way, and the slope is given in degrees, not as a percentage.

For the nomenclature of the plants we have referred to the works of Valdés et al. (2002) for Northern Morocco, Fennane et al. $(1999 ; 2007)$ and Jahandiez \& Maire (1931) for the rest of the country. The names of the syntaxa agree with the international code of Phytosociological Nomenclature (Weber et al., 2000).

\section{RESULTS}

Several associations, some of them already described and others hitherto not recognized, have been detected and are described in the following section. For each one of them their structure, floristic composition, ecology and distribution is described, along with their syntaxonomy, relation with other associations and evolution. The syntaxonomic synopsis of the syntaxa mentioned in the text is compiled in Appendix 1.

\section{Anthyllido polycephalae-Stachydetum fontqueri Quézel, Barbero, Benabid, Loisel \& Rivas Martínez 1988 subassoc. quercetosum rotundifoliae subassoc. nova}

This subassociation (Table 1) is a dense scrub dominated by various shrubs or by shrub-size trees. Among species characteristic of this association it is worth making special mention of some endemic species of limited distribution: Stachys fontqueri, Origanum grosii, Hedera maderensis subsp. iberica, Digitalis laciniata, Lithodora maroccana (Fennane \& Ibn Tattou, 1998). Stachys fontqueri is an endemic plant of the West Rif Area; Origanum grosii is an endemic also, referred from W Rif and C Rif and Targuist, where it is rare; the same applies to Digitalis lacini$a t a$, referred from W Rif, Targuist and Imzzourène; Lithodora maroccana and Hedera maderensis subsp. iberica have a wider distribution. The subassociation is characterized by the presence of Quercus rotundifolia, Hedera maderensis subsp. iberica, Rubia peregrina, Smilax aspera and Pistacia lentiscus.

This type of maquis is found in the Quercus rotundifolia domain. It colonizes principally the south-facing slopes, to a lesser degree the western ones, and somewhat rarely east-facing expositions, at between 1,000 and 1,400 m. In the Rif mountain areas where it develops it comes under the influence of maritime winds loaded with humidity proceeding from the Atlantic Ocean and Mediterranean Sea (Fig. 1).

These winds as they enter the mountainous region condense and form fog banks which are frequent in the upper Rif elevations nearer the coast. This maquis colonizes the southern slopes of the ranges affected by these fogs, but only in those where a strong contrast exists between both sides, since the sunnier conditions of the south-facing slopes are not compensated for by the humidity of the fog. 
Table 1. Anthyllido polycephalae-Stachydetum fontqueri subassoc. quercetosum rotundifoliae. Provenance of relevés: 1-2 Morocco, Rif Occidental, Jbel Assillenh, towards Tazaout, 35 13' N 5 04' W, between 1,150-1,160 m; 3-4 Morocco, Rif Occidental, Jbel Tissouka, above Chefchaouene, $35^{\circ} 10^{\prime}$ N $5^{\circ}$ 13' $\mathrm{W}$, between 1,380-1,400 m; 5-6 Morocco, Rif Occidental, Jbel Tissouka, above Mechkralla, 35ㅇ 09' N 5' 14' W, between 1,390-1,400 m; 7 Morocco, Rif Occidental, Jbel Tissouka,

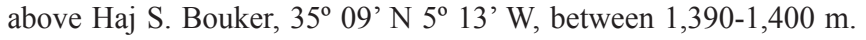

\begin{tabular}{|c|c|c|c|c|c|c|c|}
\hline Number of relevé & 1 & 2 & 3 & 4 & 5 & 6 & 7 \\
\hline Aspect & $\mathrm{S}$ & $\mathrm{S}$ & $\mathrm{W}$ & $\mathrm{S}$ & $\mathrm{E}$ & $\mathrm{E}$ & W \\
\hline Slope & 15 & 10 & 10 & 40 & 25 & 25 & 15 \\
\hline Cover & 100 & 100 & 100 & 100 & 100 & 100 & 100 \\
\hline Vegetation height (m) & $1-1.5$ & $1-1.5$ & $1-1.5$ & $1.5-2$ & $1-1.5$ & $1.5-2$ & $1.5-2$ \\
\hline Altitude (x10) & 115 & 116 & 138 & 139 & 140 & 139 & 139 \\
\hline Studied surface $\left(\mathrm{m}^{2}\right)$ & 60 & 40 & 50 & 70 & 60 & 50 & 60 \\
\hline \multicolumn{8}{|l|}{ Characteristics of the subassociation } \\
\hline Quercus rotundifolia & 2.3 & 2.2 & 4.4 & 2.2 & 4.4 & 4.4 & 3.4 \\
\hline Hedera maderensis subsp. iberica & . & . & + & . & 1.1 & 1.1 & . \\
\hline Rubia peregrina & . & . & + & 1.1 & 1.1 & 1.1 & . \\
\hline Smilax aspera & . & . & + & . & . & + & . \\
\hline \multicolumn{8}{|c|}{ Characteristics of the association and of the superior units } \\
\hline Stachys fontqueri & 2.2 & 2.2 & 2.1 & 2.2 & 2.2 & 2.2 & 1.1 \\
\hline Origanum grosii & 1.1 & 1.1 & 2.1 & 2.3 & 2.3 & 2.3 & + \\
\hline Ptilostemon riphaeus subsp. riphaeus & . & . & . & . & . & + & + \\
\hline Cistus albidus & 1.1 & . & 2.1 & 2.3 & 2.3 & 2.3 & . \\
\hline Digitalis laciniata subsp. riphaea & . & . & + & . & + & . & . \\
\hline Lithodora maroccana & . & . & . & . & . & + & 1.1 \\
\hline Ononis aragonensis & . & . & . & . & . & . & 2.2 \\
\hline Avenula gervaisii subsp. arundana & . & . & . & + & . & . & . \\
\hline Pistacia lentiscus & . & . & 1.1 & . & . & + & . \\
\hline \multicolumn{8}{|l|}{ Characteristics of the Quercetea ilicis } \\
\hline Daphne gnidium & 1.1 & . & 1.1 & . & 1.1 & 1.1 & 1.1 \\
\hline Juniperus oxycedrus subsp. oxycedrus & + & . & . & . & 1.1 & . & 3.3 \\
\hline Juniperus phoenicea & . & . & + & 2.2 & . & . & . \\
\hline Euphorbia characias subsp. characias & . & . & + & + & + & + & . \\
\hline \multicolumn{8}{|l|}{ Companions } \\
\hline Rubus ulmifolius & . & . & + & + & + & + & . \\
\hline Brachypodium retusum & 1.1 & . & 1.1 & 1.1 & 1.1 & . & . \\
\hline Euphorbia nicaensis & . & . & + & . & . & . & 1.1 \\
\hline Viola suavis & + & + & . & . & . & . & . \\
\hline Melica minuta & + & . & + & . & . & + & . \\
\hline Piptatherum paradoxum & . & . & + & . & + & . & . \\
\hline Aristolochia paucinervis & . & . & . & . & + & + & . \\
\hline Chamaerops humilis & + & + & . & . & . & . & . \\
\hline $\begin{array}{l}\text { Species annotated in a single relevé } \\
\text { hispanica } 3(+) \text {; Pimpinella tragium }\end{array}$ & allis & 1( & duus & phalu & ; Da & omer & usbp. \\
\hline
\end{tabular}

The typical Anthyllido polycephalae-Stachydetum fontqueri (Table 2) was described from Jbel Kelti, above Tamalout and from the southern slopes of Talassentane (Quézel et al., 1988).

This subassociation at present is known from Jbel Tissouka and Jbel Tazaout. The two mas- sifs constitute the highest mountains in the $\mathrm{W}$ Rif dorsal. The newly-described subassociation should be included in the alliance PseudoscabiosoOriganion grosii Quézel, Barbero, Benabid, Loisel \& Rivas-Martínez 1988 (Quézel et al., 1988). 


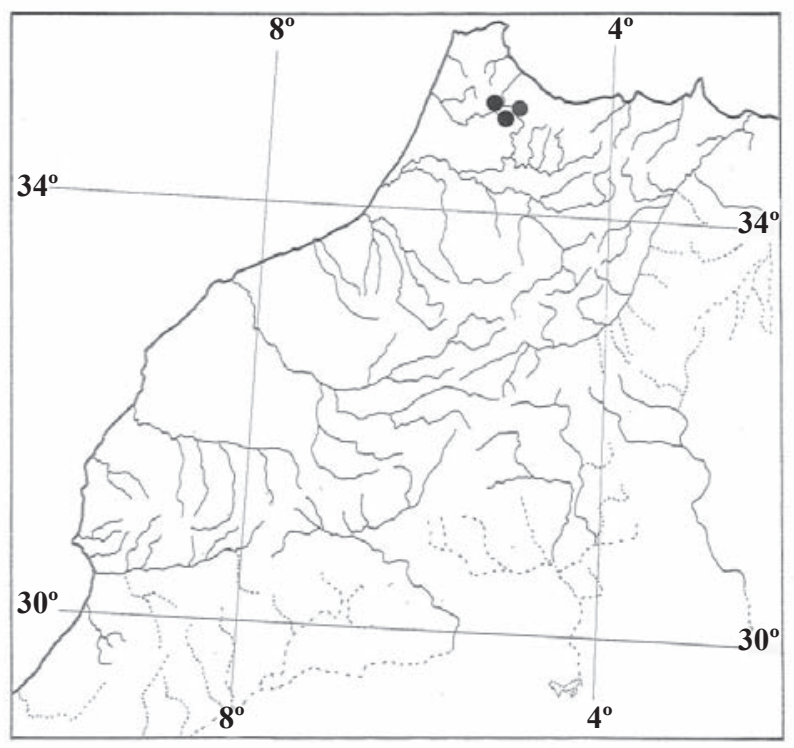

Figure 1. Distribution of Anthyllido polycephalae-Stachydetum fontqueri subassoc. quercetosum rotundifoliae.

As the holotypus, relevé 3 of Table 1 has been chosen.

On deeper soils and those with a less-pronounced slope, this association can evolve toward Paeonio maroccanae-Quercetum rotundifoliae Barbero, Quézel \& Rivas-Martínez 1981, which in the W Rif is found between 800 and 1,400 $(1,500) \mathrm{m}$. This forest community, though more typical of south-facing aspects, is also found on north-facing ones. The usual case is the presence of this maquis as constituting a permanent community on sunny expositions between 1,000 and 1,400 $(1,500) \mathrm{m}$. On shady slopes it is substituted by formations of Paeonio maroccanae-Quercetum canariensis Barbero, Quézel \& Rivas-Martínez 1981, between $(1,200) 1,300$ and $1,500 \mathrm{~m}$. On higher ground this maquis disappears as from $1,500 \mathrm{~m}$ on the shady, and $1,800-1,900 \mathrm{~m}$ on the sunny sides. Above these altitudinal limits communities of Paeonio maroccanaeAbietetum maroccanae Barbero, Quézel \& RivasMartínez 1981 can be found.

\section{Polysticho setiferi-Prunetum lusitanicae Barbero, Quézel \& Rivas-Martínez 1981}

Dense riverine woodland (Table 3), dominated by Prunus lusitanica and different species of Quercus, which attain a modest size. Beneath the tree canopy an herbaceous stratum with shade
Table 2. Comparative table of the two subassociations: (A), Anthyllido polycephalae-Stachydetum fontqueri subassoc. typicum (résumé of 8 relevés) from Quézel et al. (1988); (B), Anthyllido polycephalae-Stachydetum fontqueri subassoc. quercetosum rotundifoliae (résumé of 7 relevés) from this paper.

\begin{tabular}{|c|c|c|}
\hline Characteristics of the subassociation & A & B \\
\hline Quercus rotundifolia & - & 7 \\
\hline Hedera maderensis subsp. iberica & - & 3 \\
\hline Rubia peregrina & - & 4 \\
\hline Smilax aspera & - & 2 \\
\hline Pistacia lentiscus & - & 2 \\
\hline \multicolumn{3}{|l|}{ Characteristics of the association } \\
\hline Stachys fontqueri & 8 & 7 \\
\hline Anthyllis polycephala & 3 & - \\
\hline \multicolumn{3}{|l|}{ Characteristics of alliance } \\
\hline Salvia interrupta subsp. paui & 2 & - \\
\hline Pseudosacbiosa grosii & 6 & - \\
\hline Origanum grosii & 4 & 7 \\
\hline Ptilostemum riphaeum & 2 & 2 \\
\hline \multicolumn{3}{|l|}{ Characteristics of order and class } \\
\hline Ulex parviflorus & 5 & - \\
\hline Cistus albidus & 5 & 5 \\
\hline Satureja graeca & 5 & - \\
\hline Helianthemum cinereum subsp. rotundifolium & 3 & - \\
\hline Aphyllanthes monspeliensis & 3 & - \\
\hline Cerastium gibraltaricum & 2 & - \\
\hline Ononis aragonensis & - & 1 \\
\hline Avenula gervaisii subsp. arundana & - & 1 \\
\hline \multicolumn{3}{|l|}{ Characteristics of Quercetea ilicis } \\
\hline Buxus balearica & 3 & - \\
\hline Juniperus oxycedrus & 2 & 3 \\
\hline Juniperus phoenicea & 2 & 2 \\
\hline Daphne gnidium & 1 & 5 \\
\hline Euphorbia characias & 1 & 4 \\
\hline
\end{tabular}

loving woodland species is developed. The following species stand out: Athyrium filix-femina, Blechnum spicant, Paeonia coriacea var. maroccana and Hedera maderensis subsp. iberica.

This river woodland, located in the wetter zones of the mid mountain level, in the deciduous forest domain, meets with favourable conditions between 1,100 and 1,400 m. It extends along the entire dorsal western Rif from Bou Hassim and Jbel Kelti to Jbel Tiziren and the Central Rif (Deil, 1984). Beyond this mountain and towards the East the climate becomes more markedly continental and these riverine woodlands disappear (Fig. 2). These localities increase the distribution 
Table 3. Polysticho setiferi-Prunetum lusitanicae. Provenance of relevés: 1-2 Morocco, Rif Occidental, Bou Hassim, above Boubiyene, 35 $15^{\prime}$ N $5^{\circ}$ 25' W, between 1,180-1,200 m; 3-4 Morocco, Rif Occidental, Bou Hassim, above El Maouzkir, $35^{\circ} 14^{\prime} \mathrm{N} 5^{\circ} 25^{\prime}$ W, between 1,190-1,210 m; 5-7 Morocco, Rif Occidental, Jbel Kelti, above Tamolout, between, $35^{\circ} 21^{\prime} \mathrm{N}$ $5^{\circ} 18^{\prime} \mathrm{W}, 1,300-1,360$ m; 8 Morocco, Rif Cental, Jbel Tizirene, above Bab Barret, 35º 01' N 4 55' W, 1,500 m.

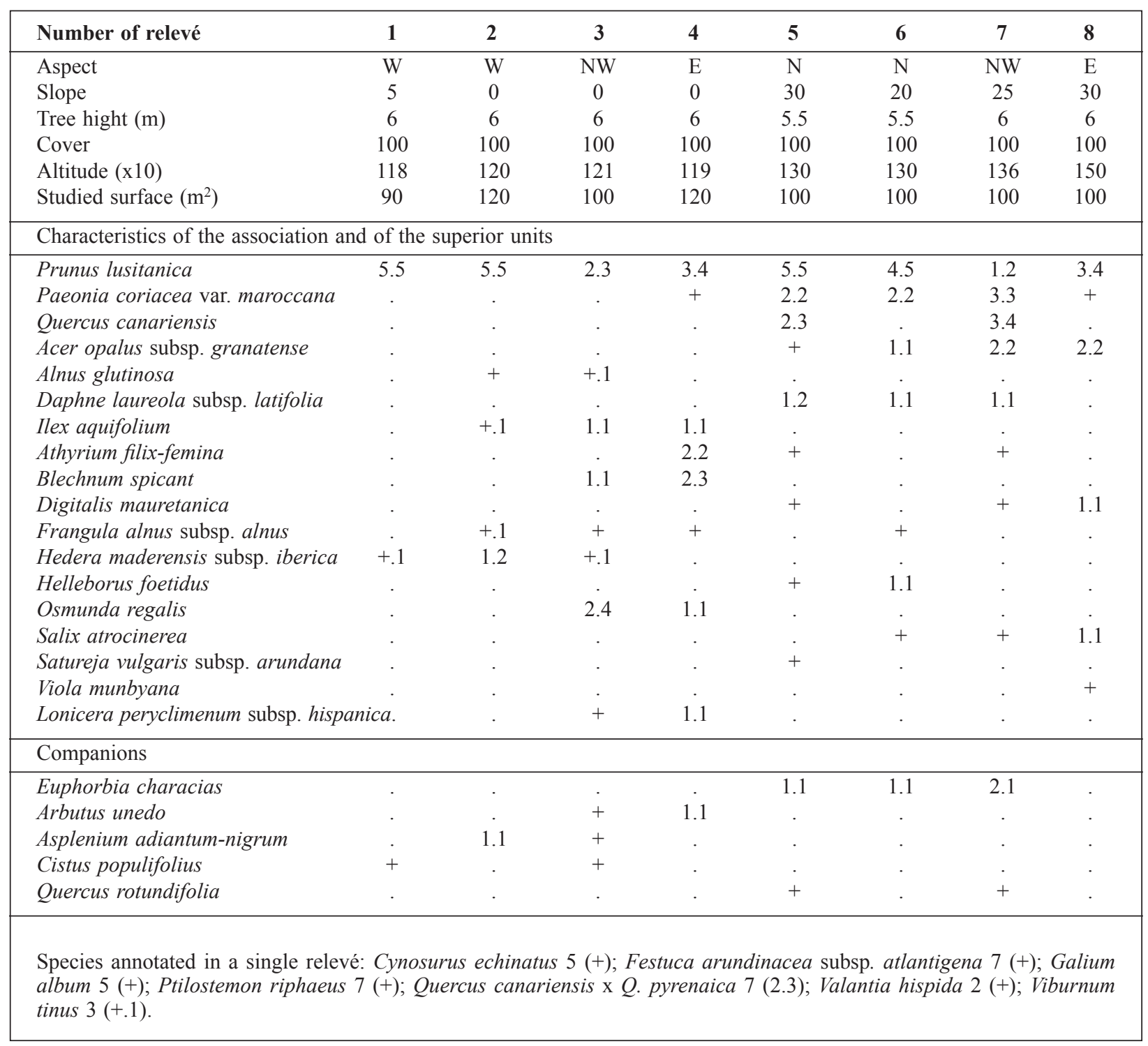

of this association, which was described from the northern slopes of the Tidighine range and $\mathrm{Bab}$ Besen (Barbero et al., 1981: 409).

This association is included in the alliance Violo munbyanae-Cedrion atlanticae Barbero, Quézel \& Rivas-Martínez 1981.

The destruction of these woods generates dense bramble thickets which, if in turn disturbed, give way to hygronitrofilous grassland, rich in banal, nitrophilous plants.

\section{Primulo acaulis-Betuletum celtibericae Barbero, Quézel \& Rivas-Martínez 1981 = Polysticho setiferi-Prunetum lusitanicae subassoc. betuletosum Deil 1984}

The birch woods are low-density woodlands that only possess a tree layer which is generally monospecific, along with an herbaceous layer dominated by frondose plants with large tender leaves (Table 4). 


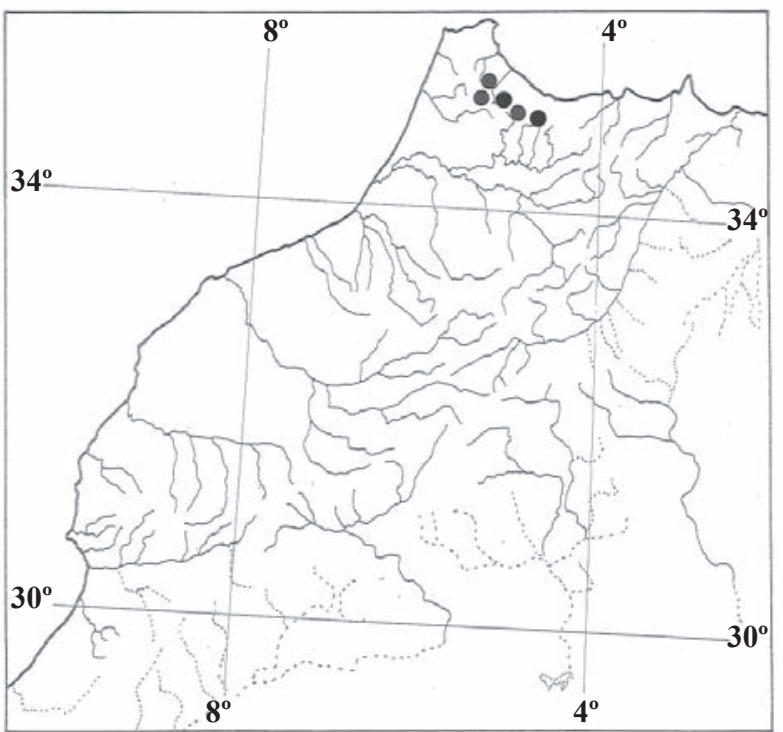

Figure 2. Distribution of Polysticho setiferi-Prunetum lusitanicae.

These woods cover limited areas of north-facing slope in the dorsal central Rif mountains, where they can be found in the wetter zones, albeit within areas possessing a markedly continental climate.

Up to now, only a few stations in the Jbel Dadoh have been located, and these occur within the cedar woodland domain. This new station must be added to those of the description in the Jbel Tidighin, Ketama and Bab Besen (Barbero et al., 1981) and Deil (1984) (Fig. 3).

These birch woods can be considered as relict communities, being found here at the southern limit of their distribution. The destruction of these communities leads to the colonization of their habitat by plants characteristic of nitrophilous herbaceous communities and also to bracken (Pteridium aquilinum) infestation.

It must be included in the order Querco-Cedretalia atlanticae Barbero, Loisel \& Quézel, 1974 and Violo munbyanae-Cedrion atlanticae Barbero, Quézel \& Rivas-Martínez 1981 alliance.

Genisto anglicae-Ericetum ciliaris Quézel, Barbero, Benabid, Loisel, \& Rivas-Martínez 1988 subsassoc. pinguiculetosum lusitanicae subassoc. nova

Heathland dominated by small chamaephytes: Genista ancistrocarpa, Erica ciliaris and Potentilla erecta, and hemicryptophytes: Carex sp. pl., Potentilla erecta, Osmunda regalis (Table 5).
Table 4. Primulo acaulis-Betuletum celtibericae. Provenance of the relevés: 1-2 Morocco, Rif Central, Jbel Daddoh (Dedokh), vers Tizi-n Tigrout, $34^{\circ} 55^{\prime} \mathrm{N} 4^{\circ} 38^{\prime}$ E, between 1,480-1,490 m; 3-4 Morocco, Rif Central, Jbel Daddoh (Dedokh), above Ketama, 34 ${ }^{\circ} 55^{\prime}$ N $4^{\circ} 37^{\prime}$ $\mathrm{W}$, between 1,480-1,500 m.

\begin{tabular}{|c|c|c|c|c|}
\hline Number of relevé & 1 & 2 & 3 & 4 \\
\hline Aspect & $\mathrm{N}$ & $\mathrm{N}$ & $\mathrm{N}$ & $\mathrm{N}$ \\
\hline Slope & 10 & 15 & 15 & 15 \\
\hline Cover & 50 & 70 & 70 & 70 \\
\hline Altitude (x10) & 148 & 149 & 148 & 150 \\
\hline Studied surface $\left(\mathrm{m}^{2}\right)$ & 100 & 90 & 100 & 100 \\
\hline \multicolumn{5}{|c|}{$\begin{array}{l}\text { Characteristics of the association and of the superior } \\
\text { units }\end{array}$} \\
\hline Betula pendula subsp. fontqueri & 2.3 & 2.3 & 3.3 & 2.2 \\
\hline Primula acaulis subsp. atlantica & 2.3 & 3.3 & 2.3 & 2.3 \\
\hline Mycelis muralis & 2.1 & 1.1 & 1.1 & 1.1 \\
\hline Poa nemoralis & 1.1 & 2.2 & 1.1 & 1.1 \\
\hline Sanicula europaea & 1.1 & 1.1 & + & 1.1 \\
\hline Salix atrocinerea & 2.2 & + & . & . \\
\hline Myosotis decumbens subsp. rifana & & 1.1 & . & + \\
\hline Galium rotundifolium & 2.3 & 1.1 & + & + \\
\hline Geum sylvaticum & +.1 & + & + & + \\
\hline Digitalis mauretanica & . & 1.1 & + & + \\
\hline \multicolumn{5}{|l|}{ Companions } \\
\hline Aira cupaniana & 1.1 & + & . & + \\
\hline Cedrus atlantica & . & + & . & + \\
\hline Prunella vulgaris & . & + & . & . \\
\hline Pteridium aquilinum & + & 1.1 & + & + \\
\hline Ranunculus repens & 1.1 & 2.2 & + & 1.1 \\
\hline
\end{tabular}

These constitute among the most clearly represented groups of vegetation showing an Atlantic affinity of those in the Mediterranean landscape observed here.

Within this community numerous hygrophilous species appear, among them Pinguicula lusitanica and Oenanthe maroccana, these being rare in the territory as a whole. This association colonizes the edges of permanent watercourses, such as the small streams in the Bou Hassim massif. This receives the full impact of the Atlantic oceanic influence. Its north- and south-facing aspects aid the condensation of moisture-laden winds which blow towards the east. Within the massif, the high precipitation favours the presence of springs and permanent streams, wellsupplied even in the height of summer. This community colonizes the permanently moist soils of an acidic nature on level or slightly sloping ground. It enters into contact with Alnus glutinosa in the general domain of Quercus canariensis woodland. 


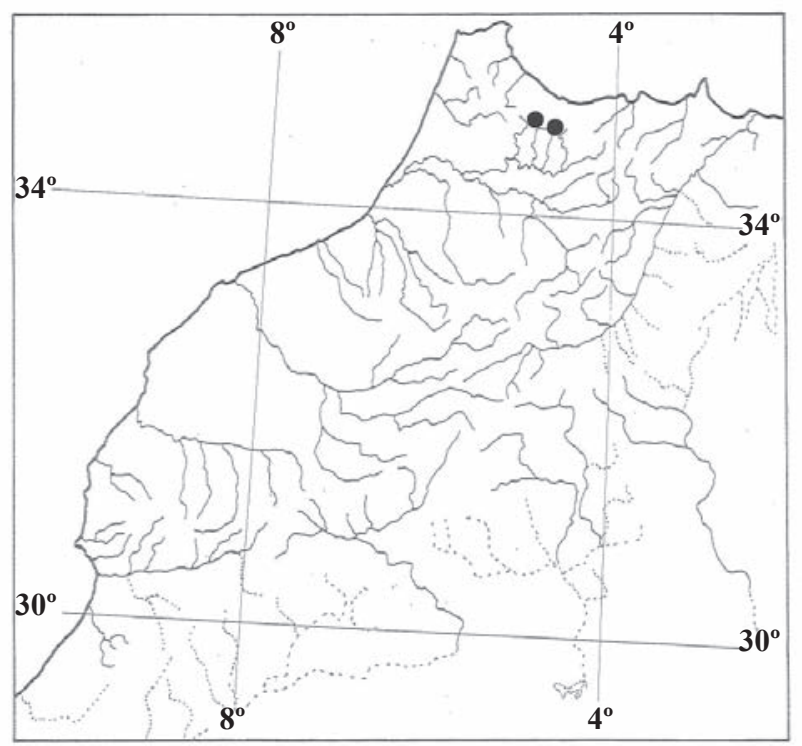

Figure 3. Distribution of Primulo acaulis-Betuletum celtibericae.
It can be found from $1,200 \mathrm{~m}$ up to $1,400 \mathrm{~m}$, in Quercus canariensis woodland domain, in gully bottoms containing streams, and oriented in a north to north-easterly direction. In these, it colonizes the stream edges in the montane zone of the W Rif, where it is known from the Bou Hassim massif (Fig. 4).

Floristically poor due to its relictic nature in the limits of its area, it appears that this community can be included within the sub-Iberian alliance Genistion micrantho-anglicae Rivas-Martínez 1979.

It is closely related to the Genisto anglicaeEricetum ciliaris subassoc. typicum described from the Tanger Region (Tangerois), from the surroundings of boggy ground in the Southern part of the El Araix woodlands and Khemis Sahel, between 130 and $360 \mathrm{~m}$. As has been noted by Loidi et al. (2007) these Moroccan heaths occupy a very reduced extension and they contain several endemic taxa, which could be the result of an ancient establishment of this vegetation type. Time

Table 5. Genisto anglicae-Ericetum ciliaris subsass. pinguiculetosum lusitanicae. Provenance of relevés: 1-3 Morocco, Mountains of W Rif, Bou Hassim, above Boubiyene, 35 15' N 526' W, between 1,190-1,300 m; 4-5 Morocco, Mountains of W Rif, Bou Hassim, above El Maouzkir, 35 $14^{\prime}$ N 5 $5^{\circ} 24^{\prime}$ W, between 1,300-1,360 m.

\begin{tabular}{|c|c|c|c|c|c|}
\hline Number of relevé & 1 & 2 & 3 & 4 & 5 \\
\hline Aspect & $\mathrm{N}$ & $\mathrm{NE}$ & $\mathrm{N}$ & $\mathrm{N}$ & $\mathrm{N}$ \\
\hline Slope & 5 & 5 & 5 & 5 & 5 \\
\hline Cover & 100 & 100 & 100 & 100 & 100 \\
\hline Altitude (x10) & 121 & 119 & 130 & 130 & 136 \\
\hline Studied surface $\left(\mathrm{m}^{2}\right)$ & 20 & 16 & 20 & 20 & 20 \\
\hline \multicolumn{6}{|c|}{ Characteristics of the subassociation } \\
\hline Blechnum spicant & 1.1 & 2.2 & . & 2.3 & 2.2 \\
\hline Pinguicula lusitanica & . & . & 1.1 & + & . \\
\hline Oenanthe maroccana & . & . & 1.1 & 1.1 & . \\
\hline \multicolumn{6}{|c|}{ Characteristics of the association and of the superior units } \\
\hline Erica ciliaris & 2.3 & 1.2 & 1.2 & 4.5 & 2.3 \\
\hline Genista ancistrocarpa & 2.3 & + & . & + & . \\
\hline Potentilla erecta & 2.2 & 2.2 & 1.1 & 2.2 & 1.1 \\
\hline Calluna vulgaris & . & . & . & + & . \\
\hline Danthonia decumbens & . & . & . & + & . \\
\hline Lythrum junceum & 1.1 & . & . & . & . \\
\hline Anagallis tenella & . & . & 1.2 & . & . \\
\hline \multicolumn{6}{|l|}{ Companions } \\
\hline Osmunda regalis & . & 1.1 & . & 2.2 & 1.1 \\
\hline Alnus glutinosa & 1.1 & . & + & . & . \\
\hline Lotus hispidus & 1.1 & . & . & . & . \\
\hline Carex distans & . & 2.2 & . & 1.1 & 1.1 \\
\hline Pteridium aquilinum & . & . & 1.1 & + & . \\
\hline Carex demissa & . & . & 2.3 & . & + \\
\hline Carex flaca subsp. serrulata & . & . & . & + & . \\
\hline
\end{tabular}




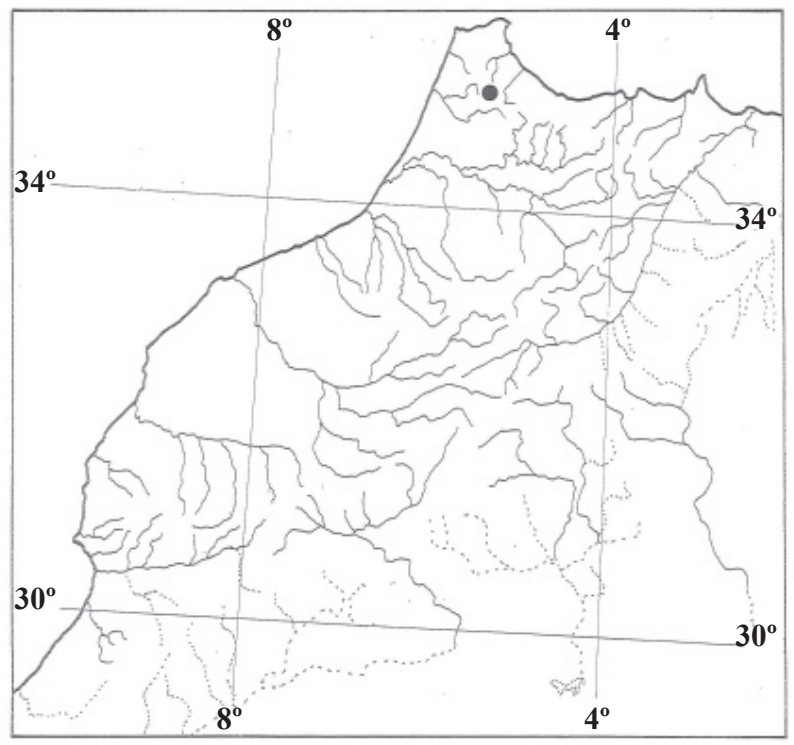

Figure 4. Distribution of Genisto anglicae-Ericetum ciliaris subsassoc. pinguiculetosum lusitanicae.

and isolation have probably enhanced speciation in these rainy areas and where the presence of wet soils has favoured this process.

The difference between both subassociations can be recognized in the adjoining table (Table 6). This new syntaxa is recognized by the lack of Anagallis crassifolia, Erica scoparia and Halimium halimifolium. That is, it becomes poor in floristic elements of the lower-lying land, and yet is enriched by plants more characteristic of the mountains.

As holotypus of this new syntaxon, relevé 3 of Table 5 is selected.

\section{Cephalario maroccanae-Inuletum maletii assoc. nova}

This plant community is characterized by the presence of some endemic taxa, such as Inula maletii, Cephalaria maroccana and Paeonia coriacea var. maroccana (Table 7). In it, the megaphorbic species, plants of a high and dense habit, stand out. Such is the case of Cephalaria maroccana, capable of attaining over $1.5 \mathrm{~m}$ height, or Inula maletii, which reaches $1 \mathrm{~m}$. The habit of these plants, together with their high degree of cover, imparts a frondose and robust appearance to this association, reminding one of the megaphorbic plant communities of more northern latitudes.

Cephalaria maroccana is endemic to the High Atlas and the Central Middle Atlas (near Daya-tHachlaf and Azrou, Fennane \& Ibn Tattou, 1998).
Table 6. Comparative table of the two subassociations: (A), Genisto anglicae-Ericetum ciliaris subassoc. typicum (résumé of 5 relevés) from Quézel et al. (1988); (B), Genisto anglicae-Ericetum ciliaris subassoc. pinguiculetosum lusitanicae (résumé of 6 relevés).

\begin{tabular}{|c|c|c|}
\hline Characteristics of subassociation & $\mathbf{A}$ & B \\
\hline Pinguicula lusitanica & - & 2 \\
\hline Oenanthe maroccana & - & 2 \\
\hline Danthonia decumbens & - & 1 \\
\hline \multicolumn{3}{|l|}{ Characteristics of association } \\
\hline Erica ciliaris & 6 & 5 \\
\hline Genista ancistrocarpa & 5 & 2 \\
\hline Potentilla erecta & 6 & 5 \\
\hline Osmunda regalis & 3 & 3 \\
\hline Anagallis crassifolia & 2 & - \\
\hline \multicolumn{3}{|l|}{ Characteristics of alliance } \\
\hline Blechnum spicant & - & 4 \\
\hline Pinguicula lusitanica & - & 2 \\
\hline Calluna vulgaris & 2 & 1 \\
\hline Erica scoparia & 4 & - \\
\hline Agrostis setacea & 2 & - \\
\hline Halimium halimifolium & 1 & - \\
\hline \multicolumn{3}{|l|}{ Companions } \\
\hline Pteridiumm aquilinum & 2 & 3 \\
\hline Schoenus nigricans & 4 & - \\
\hline Inula viscosa & 4 & - \\
\hline Cistus salvifolius & 3 & - \\
\hline Myrtus communis & 2 & - \\
\hline Isoetes hystrix & 2 & - \\
\hline Myosostis sicula & 2 & - \\
\hline Eleocharis multicaulis & 2 & - \\
\hline Carex distans & 2 & 3 \\
\hline Agrostis stolonifera & 2 & - \\
\hline Sphagnum sp. & 2 & - \\
\hline Alnus glutinosa & - & 2 \\
\hline Carex flava & - & 2 \\
\hline Carex flacca subsp. serrulata & - & 1 \\
\hline Lythrum junceum & - & 1 \\
\hline Anagallis tenella & - & 1 \\
\hline
\end{tabular}

Inula maletii is restricted to the mountainous zones of the Middle Atlas (Fennane \& Ibn Tattou, 1998). Paeonia coriacea var. maroccana is widely present in the Rif and the Middle Atlas (Romo, 1992).

This community develops in the cedar woodland clearings, on north-facing aspects with a fairly gentle relief. In these clearings it colonizes the humus-rich soils in which the tussocks or necks of perennial plants leave small gaps which in turn are colonized by the annual plants.

At present the association is known only from the Michliffene massif in the Middle Atlas (Fig. 5). 
Table 7. Cephalario maroccanae-Inuletum maletii. Provenance of relevés: 1-10 Morocco, Middle Atlas, Michliffene, $33^{\circ}$ 24' N $5{ }^{\circ} 05^{\prime} \mathrm{W}$, between 1,820-1,890 m.

\begin{tabular}{|c|c|c|c|c|c|c|c|}
\hline Number of relevé & 1 & 2 & 3 & 4 & 5 & 6 & 7 \\
\hline Aspect & $\mathrm{N}$ & $\mathrm{N}$ & $\mathrm{NE}$ & NW & $\mathrm{N}$ & $\mathrm{N}$ & $\mathrm{N}-\mathrm{NW}$ \\
\hline Slope & 30 & 28 & 32 & 35 & 30 & 30 & 35 \\
\hline Cover & 80 & 90 & 35 & 35 & 35 & 90 & 95 \\
\hline Altitude (x10) & 189 & 184 & 183 & 184 & 185 & 185 & 187 \\
\hline Studied surface $\left(\mathrm{m}^{2}\right)$ & 85 & 35 & 40 & 20 & 30 & 80 & 90 \\
\hline \multicolumn{8}{|c|}{ Characteristics of the association and of the superior units } \\
\hline Cephalaria maroccana & 4.5 & 4.5 & 3.4 & 3.3 & 4.5 & 3.4 & 4.5 \\
\hline Inula maletii & 2.3 & 2.3 & 2.2 & 1.2 & 2.3 & 2.3 & 2.3 \\
\hline Geum atlanticum & . & . & . & . & . & + & 1.2 \\
\hline Paeonia coriacea var. maroccana & . & . & 1.1 & 1.1 & 1.2 & 1.2 & 1.2 \\
\hline Crepis vesicaria & 1.1 & . & 2.1 & 1.1 & 1.1 & 1.1 & 1.1 \\
\hline Saponaria glutinosa & . & + & +.1 & . & . & 1.2 & 1.1 \\
\hline Armeria alliacea & . & + & . & . & . & . & 1.1 \\
\hline Delphinium obcordatum & & & + & 1.2 & & & \\
\hline \multicolumn{8}{|l|}{ Companions } \\
\hline Quercus rotundifolia & 1.2 & + & . & . & + & . & 1.1 \\
\hline Cedrus atlantica & . & . & +.1 & 1.2 & + & . & + \\
\hline Poa bulbosa & 1.1 & . & 1.1 & . & + & 1.1 & 1.1 \\
\hline Bromus hordeaceus & 1.2 & 2.2 & 1.1 & 2.2 & . & 1.2 & 1.2 \\
\hline Dianthus sylvestris & + & . & + & . & . & + & + \\
\hline Cynosurus echinatus & + & + & . & . & 1.1 & 1.2 & + \\
\hline Rosa canina & . & . & 1.1 & 1.1 & . & . & 1.1 \\
\hline Galium lucidum & . & + & + & 1.1 & . & . & 1.1 \\
\hline Petrorhagia prolifera & . & 1.1 & 1.1 & 1.2 & 1.1 & . & 1.1 \\
\hline Vicia sp. & . & + & . & . & . & . & + \\
\hline Satureja vulgaris & & & + & + & & & 1.1 \\
\hline Poa pratensis & & & & 1.1 & & & + \\
\hline Catananche coerulea & & & & & & & + \\
\hline Alyssum alyssoides & & + & & & & + & . \\
\hline Xeranthemum inapertum & 1.1 & 1.1 & & 1.1 & & + & . \\
\hline Helianthemum apenninum & 1.2 & & 1.1 & & & . & 1.1 \\
\hline Jurinaea humilis & 1.2 & & & & & & \\
\hline Mantisalca salmantica & & + & & & & & \\
\hline Onosma fastigiata var. maroccana & & & & + & & & \\
\hline Crataegus laciniata & & & & & & . & + \\
\hline Arenaria serpylllifolia & & + & & & & & + \\
\hline Echinaria capitata & & & & & & & + \\
\hline Arenaria leptoclados & & & & & & & + \\
\hline Cerastium sp. & & & & & + & & \\
\hline Dactylis glomerata subsp. hispanica & & + & 1.1 & & & & \\
\hline Crucianella angustifolia & & + & & & & & \\
\hline Elymus repens & & + & & & & & \\
\hline Erysimum incanum & & & & & & & + \\
\hline Linaria $\mathrm{sp}$ & & + & + & & & & \\
\hline Hieracium sp. & & & & & & & + \\
\hline Rosa spinosissima & & & + & & & & \\
\hline Thlaspi perfoliatum & & & & & + & & \\
\hline Caucalis platycarpos & & + & & & & & + \\
\hline
\end{tabular}

This zone is distinct due to its receiving humidityladen air masses, which deposit copious snow in winter and abundant precipitations in autumn and spring. The only ski-station that exists at present in the Middle Atlas is found close by, and serves as proof of these climatic conditions. 
The assigning of a phytosociological alliance in which to nest this new syntaxon is not an easy matter, due to the poor representation of structural taxa present in the more boreal megaphorb communities, and in contrast the presence of numerous species of a Mediterranean character.

The natural evolution of these megaphobic communities is towards forest formations. Dendrotaxons such as Quercus rotundifolia and $\mathrm{Ce}$ drus atlantica act as witnesses to this, indicating an evolution towards more or less pure forest stands of Cedrus atlantica.

As holotypus of this new syntaxon, relevé 6 of Table 7 is selected.

\section{Bellis caerulescendis-Heracletum sphondyllii assoc. nova}

This megaforbic community is made up of herbaceous plants of considerable size, with tender, frondose leaves. Among these, representatives of the genera: Heracleum, Alchemilla, Ranunculus and Polygonum stand out (Table 8).

It colonizes the permanent watercourses of the High Atlas. It is found near springs and mountain streams in shady aspects, preferably on abrupt slopes with a north-facing aspect and in gullies excavated

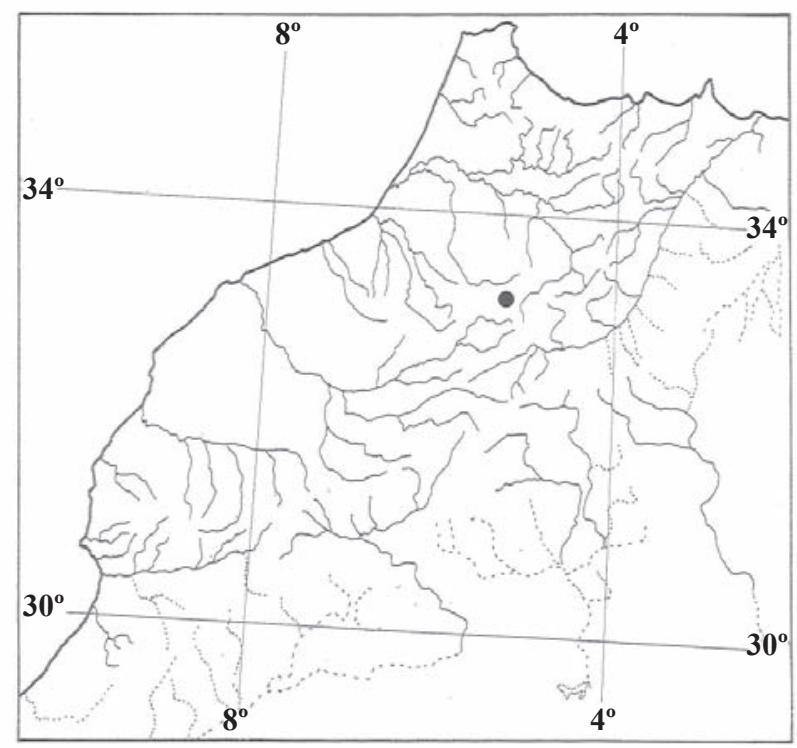

Figure 5. Distribution of Cephalario maroccanaeInuletum maletii.

by the water courses, close to cliffs, between 2,400 and 2,800 $\mathrm{m}$ (Fig. 6).

Overgrazing and the strong pressure of ski slope installations can cause an alarming reduction of these megaphorbic communities.

Table 8. Bellis caerulescendis-Heracletum sphondyllii. Provenance of relevés: 1-5 Morocco, High Atlas, Oukaïmedene area, southern slopes of Adrar Angour, $31^{\circ} 11^{\prime} \mathrm{N} 7^{\circ} 50^{\circ} \mathrm{W}$, between 2,650-2,710 m.

\begin{tabular}{|c|c|c|c|c|c|}
\hline Number of relevé & 1 & 2 & 3 & 4 & 5 \\
\hline Aspect & SW & $\mathrm{S}$ & - & - & - \\
\hline Slope & 10 & 5 & - & - & - \\
\hline Cover & 100 & 100 & 100 & 100 & 100 \\
\hline Altitude (x10) & 270 & 268 & 265 & 271 & 270 \\
\hline Studied surface $\left(\mathrm{m}^{2}\right)$ & 25 & 20 & 30 & 25 & 25 \\
\hline \multicolumn{6}{|c|}{ Characteristics of the association and of the superior units } \\
\hline Aconitum vulparia subsp. neapolitanum & 1.2 & . & 4.4 & 2.3 & 4.4 \\
\hline Alchemilla atlantica & + & . & . & . & + \\
\hline Bellis caerulescens & . & . & 1.1 & + & 1.1 \\
\hline Carex ovalis subsp. atlasica & + & + & . & . & . \\
\hline Heracleum sphondylium var. suaveolens & 3.4 & 2.3 & 3.3 & 3.3 & 2.2 \\
\hline Polygonum bistorta & 1.1 & 2.2 & 2.3 & 2.3 & . \\
\hline Ranunculus dyris & 3.3 & 5.5 & 5.5 & 5.5 & 4.4 \\
\hline \multicolumn{6}{|l|}{ Companions } \\
\hline Bromus hordeaceus & . & . & + & . & . \\
\hline Cystopteris fragilis & + & + & . & . & . \\
\hline Dactylorrhiza elata & . & + & + & . & . \\
\hline Festuca rubra & 1.1 & 1.1 & . & . & 1.1 \\
\hline Isatis tinctoria subsp. tinctoria & 1.1 & . & 1.1 & 1.1 & 1.1 \\
\hline Poa trivialis & 1.1 & 1.1 & . & . & . \\
\hline
\end{tabular}




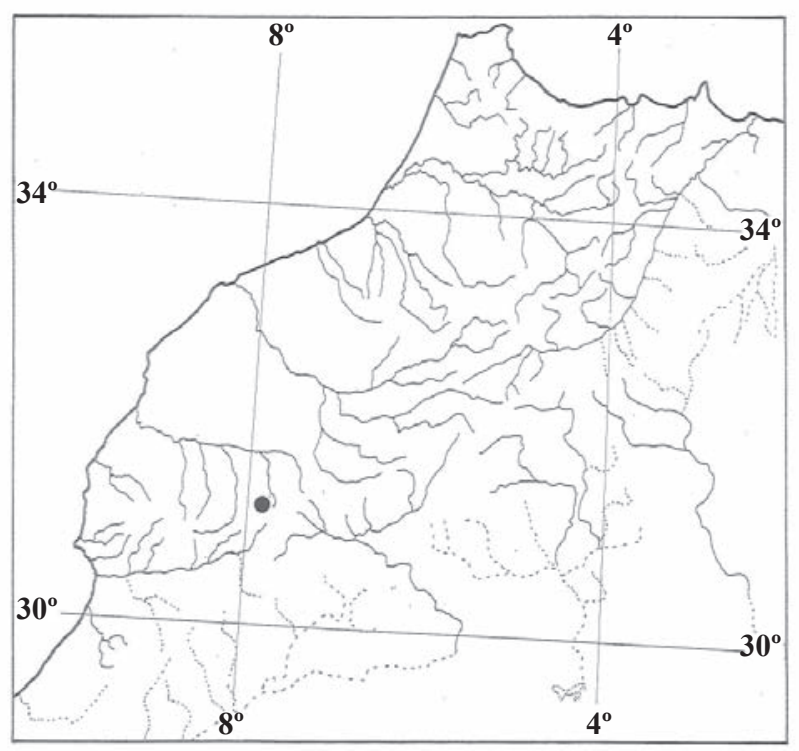

Figure 6. Distribution of Bellis caerulescendis-Heracletum sphondyllii.

It must be included in the alliance Eryngion variifoliae Quézel 1957. As holotypus of this new syntaxon, relevé 3 of Table 8 is selected.

\section{Astragaletum numidico-maroccani Quézel, Barbero, Benabid, Loisel \& Rivas-Martínez 1988}

This plant community is made up, principally, of chamaephytes and, to a much lesser extent, of hemicriptophytes and therophytes (Table 9). Within the community certain endemic taxa, of very limited distribution, stand out: Astragalus fontianus, A. meuselii and Allium pallescens, the latter here surpassing the given altitudinal limit for the species, stated as 1,900 m by Mateos (2003).

This scrubland colonizes the crests and high plateaux above $2,000 \mathrm{~m}$, on calcareous substrate. These areas are subject to a strong solifluxion as well as cryoturbation, owing to the high altitude. They are found in the supraforestal zone, above Abies maroccana woodlands, in areas with a high mountain Mediterranean climate.

It is known from between Talassentane and Lakraa, from where this syntaxon was described, and from the Jbel Lakraa (Adrar Lexhab) massif and its surrounding mountains, and possibly also from Jbel Taloussie (Fig. 7).

It is a permanent community that colonizes extreme areas of the Mediterranean high mountain
Table 9. Astragaletum numidico-maroccani. Provenance of relevés: 1-3 Morocco, Rif Occidental, Jbel Lakraa or Adrar

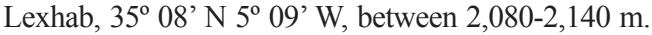

\begin{tabular}{|lcccc|}
\hline Number of relevé & $\mathbf{1}$ & $\mathbf{2}$ & $\mathbf{3}$ & $\mathbf{4}$ \\
\hline Aspect & $\mathrm{W}$ & - & - & - \\
Slope & 5 & - & - & - \\
Cover & 25 & 40 & 30 & 40 \\
Altitude (x10) & 210 & 214 & 208 & 210 \\
Studied surface $\left(\mathrm{m}^{2}\right)$ & 80 & 70 & 80 & 80 \\
\hline Characteristics of the association & and of the superior \\
units & & & & \\
\hline Astragalus meuselii & 1.2 & 2.2 & 2.3 & 1.2 \\
Alyssum spinosum & 2.2 & 1.2 & 2.2 & 1.2 \\
Arenaria armerina & 1.1 & + & 1.1 & + \\
Linaria tristis subsp. pectinata & 1.1 & $\cdot$ & + & + \\
Astragalus fontianus & $\cdot$ & + & + & + \\
Cynoglossum cheirifolium & & & & \\
subsp. heterocarpum & $\cdot$ & + & + & + \\
Bupleurum spinosum & 2.2 & 1.2 & $\cdot$ & 1.1 \\
\hline Companions & & & & \\
\hline Festuca hystrix & 1.2 & 1.3 & 1.2 & 2.2 \\
Allium pallens subsp. pallens & + & $\cdot$ & + & + \\
Bromus hordeaceus & + & $\cdot$ & + & $\cdot$ \\
Bromus sterilis & $\cdot$ & + & + & $\cdot$ \\
Sedum album & + & $\cdot$ & + & $\cdot$ \\
Sedum acre & + & + & $\cdot$ & + \\
\hline
\end{tabular}

environment. Its destruction leads to an increase of the annual plants and slightly nitrophilous hemicriptophytes.

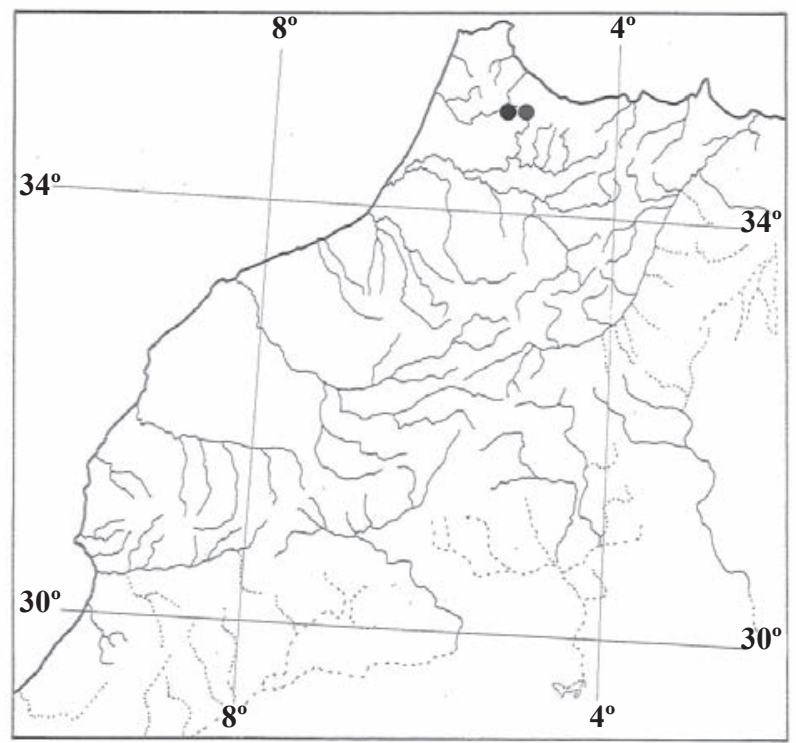

Figure 7. Distribution of Astragaletum numidicomaroccani. 
Table 10. Arenario armerinae-Sideritetum matris-filiae. Provenance of relevés: 1-7 Morocco, Middle Atlas, Jbel Tichchoukt, near Lalal-Oum-el-Bent, $33^{\circ} 23^{\prime} \mathrm{N} 4^{\circ} 40^{\prime} \mathrm{W}$, between 2,600-2,650 m.

\begin{tabular}{|c|c|c|c|c|c|c|c|c|}
\hline Number of relevé & 1 & 2 & 3 & & 4 & 5 & 6 & 7 \\
\hline Aspect & $\mathrm{N}$ & $\mathrm{N}$ & $\mathrm{N}$ & & NW & $\mathrm{S}$ & $\mathrm{N}$ & $\mathrm{N}$ \\
\hline Slope & 15 & 30 & 10 & & 15 & 20 & 15 & 15 \\
\hline Cover & 40 & 40 & 45 & & 45 & 30 & 35 & 40 \\
\hline Altidude (x10) & 260 & 261 & 264 & & 264 & 265 & 263 & 262 \\
\hline Studied surface $\left(\mathrm{m}^{2}\right)$ & 80 & 80 & 60 & & 70 & 50 & 80 & 70 \\
\hline \multicolumn{9}{|c|}{ Characteristics of the association and of the superior units } \\
\hline Arenaria armerina & 1.2 & 1.1 & 1.1 & & . & + & 2.2 & 1.2 \\
\hline Bupleurum spinosum & 2.3 & 1.1 & 2.3 & & 2.2 & 1.1 & 2.3 & 2.2 \\
\hline Carduncellus atractyloides & 1.2 & 2.2 & 2.2 & & 1.1 & . & + & 1.1 \\
\hline Festuca hystrix & 2.2 & 1.1 & 2.1 & & + & . & 1.1 & 2.2 \\
\hline Helictotrichon jahandiezii & . & + & 1.1 & & 1.1 & . & 1.1 & + \\
\hline Jurinaea humilis & 1.1 & + & + & & + & . & 1.1 & + \\
\hline Sideritis matris-filiae & 1.1 & 2.3 & 1.1 & & 1.1 & 1.1 & 1.1 & 1.2 \\
\hline Thymus atlanticus & 1.1 & 1.1 & 1.1 & & 1.1 & 2.3 & 1.2 & 1.1 \\
\hline Alyssum atlanticum & . & . & . & & . & + & . & . \\
\hline Poa ligulata & 1.1 & 1.1 & 1.1 & & + & 1.1 & . & 1.1 \\
\hline Lactuca reviersii & . & . & . & & . & + & . & . \\
\hline \multicolumn{9}{|l|}{ Companions } \\
\hline Asperula cynanchica & 1.1 & . & . & & . & . & + & + \\
\hline Helianthemum oelandicum subsp. canum & 1.1 & 1.1 & . & & . & . & . & . \\
\hline Juniperus communis subsp. hemisphaerica & . & . & . & & . & . & +.1 & . \\
\hline Minuartia hibrida subsp. hybrida & . & . & . & & . & + & . & . \\
\hline Linum austriacum subsp. mauritanicum & . & . & . & & . & + & . & . \\
\hline Ononis cenisia & . & . & + & . & . & + & . & \\
\hline Pimpinella tragium & . & . & . & + & . & . & . & \\
\hline Sedum dasyphyllum & + & . & . & . & + & . & . & \\
\hline Satureja alpina subsp. meridionalis & . & . & + & . & . & . & . & \\
\hline Scorzonera pygmaea & . & . & . & 1.2 & . & . & . & \\
\hline
\end{tabular}

It is included in the order Erinacetalia anthyllidis Quézel 1952, and the alliance Diantho maroccaniAstragalion maroccani Quézel, Barbero, Benabid, Loisel \& Rivas Martínez 1988.

\section{Arenario armerinae-Sideritetum matris-filiae assoc. nova}

This is a high Mediterranean mountain plant community characterized by some endemics and other plants with a highly restricted distribution (Table 10).

Sideritis matris-filiae is an endemic basophilous plant from this range (Rejdali \& Fennane, 2007) and from the Bou Nacer.

Helianthemum oelandicum subsp. canum is known from the High Atlas in the Jbel Ghat and Jbel Angour near Oukaimeden to Jbel Ayachi. It becomes rare in the Middle Atlas (Bou Iblane, Bou Nacer, Guelb-er-Rahal) and Tichchoukt Range (Fennane \& Ibn Tattou, 1998).

Carduncellus atractyloides is known from the High Atlas (Rhate), and Tichchoukt Range in the Middle Atlas (Fenanne \& Ibn Tattou, 1998).

Helictotrichon jahandiezii is an endemic plant of the Middle Atlas that reaches the ranges of Bou Iblane and Tichchoukt in the North Eastern Middle Atlas.

Lactuca reviersii is rare in the High Atlas and only known in the Middle Atlas beyond this range from Bou Iblane and Guelb-er-Rahal (Fennane \& Ibn Tattou, 1998).

Juniperus communis subsp. hemisphaerica is rare in Morocco, otherwise from the Tichchoukt it is only referred from the massifs of Bou Iblane and Bou Nacer (Fennane \& Ibn Tattou, 1998) in the Middle Atlas (Fig. 8). 


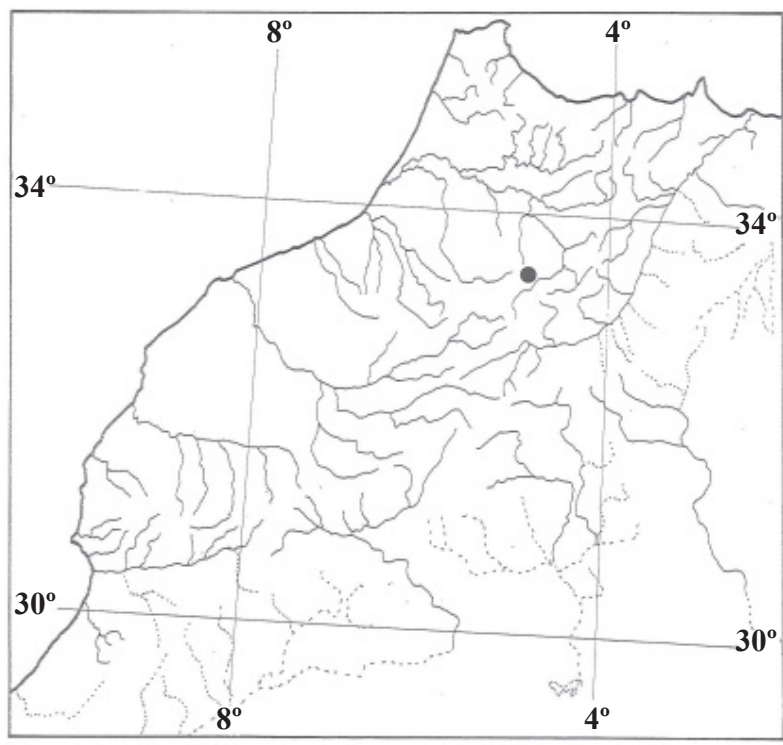

Figure 8. Distribution of Arenario armerinae-Sideritetum matris-filiae.

It colonizes rocky crests, where thin cryoturbated soils exist, from between 2600 and $2700 \mathrm{~m}$ above sea level. At present it is only known from the Tichchoukt massif, but it may well exist on the Bou Nacer Massif.

This new syntaxon must be referred to the alliance Genistion pseudopilosae-Thymion comosi Benabid 1988 included in the order Erinacetalia anthyllidis Quézel 1952, although its affinities with the alliance Minuartio-Poion ligulatae O. de Bolòs 1962 stand out. As holotypus of this new syntaxon, relevé 2 of Table 10 is selected.

\section{CONCLUSIONS}

In the present study of Moroccan mountain vegetation it becomes clear that the associations of some particular habitats usually occupying rather limited areas (as in the case of megaphorb communities, wet mountain flushes, bogs, mountain pastures, etc) are not known to the same extent as the forest and scrub communities. This is especially the case in the more isolated massifs which have long and difficult approaches, and the more remote uplands of complicated access and thus studied in a very general way from the botanical and phytosociological point of view, and practically unknown by these disciplines.

\section{ACKNOWLEDGEMENTS}

Along with this study I wish to remember the man who was our academic master, Professor Oriol de Bolòs. I will ever remain in debt to him for his initiating me into the fascinating world of the study of vegetation. Our gratitude to three anonymous reviewers, whose comments and indications permitted us to improve substantially this paper. Samuel Pyke has improved the English language.

\section{REFERENCES}

Barbero, M., Loisel, R. J. \& Quézel, P. 1974. Problèmes posés par l'interpretation phytosociologique des Quercetea ilicis et des Quercetea pubescentis. CNRS. Coll. Intern. 235: 481-497.

Barbero, M., Quézel, P. \& Rivas-Martínez, S. 1981. Contribution à l'étude des groupements forestiers et préforestiers du Maroc. Phytocoenologia 9(3): 311-412.

Benabid, A. 1982. Brief aperçu sur la zonation altitudinale de la végétation climacique du Maroc. Ecol. Medit. 8(1/2): 301-315.

Braun-Blanquet, J. 1977. Fitosociología. Editorial Blume, Madrid.

Deil, U. 1984. Zur Vegetation im Zentralen Rif (Nordmarokko). Diss. Bot. 74: 1-324.

Deil, U. 1994. Felsgesellschaften beiderseits der Strasse von Gibraltar. Hoppea 55: 757-814.

Deil, U. 1997. Vegetation cover and human impact. A comparison of the Almarchal Region (Campo de Gibraltar, Spain) and the Tangier hinterland (Morocco). Lagascalia 19: 745-758.

Dierschke, H. 1994. Pflanzensoziologie. Grundlagen und Methoden. Ulmer Verlag, Stuttgart.

Fennane, M. 2003. Inventaire des communautés végétales à l'aide du phytosociologue, au Maroc. Ecol. Medit. 29: 87-106.

Fennane, M. \& Ibn Tattou, M. 1998. Catalogue des plantes rares, menacées ou endémiques du Marroc. Bocconea 8: 5-244.

Fennane, M., Ibn Tattou, M., Mathez, J., Ouyahya, A. \& El Oualidi, J. 1999. Flore pratique du Maroc 1. Trav. Inst. Sci. Sér. Bot. 36. Éditions Okad, Rabat.

Fennane, M. \& Ibn Tattou, M. 2005. Flore vasculaire du Marroc, inventaire et chorologie 1. Trav. Inst. Sci., Sér. Bot. 37. Éditions Okad, Rabat.

Fennane, M., Ibn Tattou, M., Ouyahya, A. \& El Oualidi, J. 2007. Flore pratique du Maroc 2. Trav. Inst. Sci., Sér. Bot. 38. Éditions Okad, Rabat.

Galán de Mera, A. 1993. Flora y vegetación de los términos municipales de Alcalá de los Gazules y Medina Sidonia (Cádiz, España). Servicio de publicaciones. Universidad Complutense, Madrid. Unpublished $\mathrm{PhD}$ thesis.

Jahandiez, E. \& Maire, R. 1931-1932. Catalogue des Plantes du Maroc, 3 vols. Imprimerie Minerva, Alger.

Loidi, J., Biarrun, J., Campos, J. A., García-Mijangos, I. \& Herrera, M. 2007. A survey of heath vegetation of the Iberian Peninsula and Northern Morocco: a biogeographical and bioclimatic approach. Phytocoenologia 37(3-4): 341-370.

Mateos, M. A. 2003. Estudio florístico del Rif occidental 
calizo (N de Marruecos). Universidad de Sevilla, Sevilla. Unpublished $\mathrm{PhD}$ thesis.

Mueller-Dombois, D. \& Ellenberg, H. 1974. Aims and methods of Vegetation Ecology. John Wiley \& sons, New York, London, Sidney and Toronto.

Quézel, P. 1957. Le peuplement végétal des hautes montagnes de l'Afrique du Nord. Éditions P. Lechevalier, Paris.

Quézel, P., Barbero, M., Benabid, A., R. J. Loisel, R. \& RivasMartínez, S. 1988. Contribution à l'étude des groupements pré-forestiers et des matorrals rifains. Ecol. Medit. 14(1/2): 77-122.

Rejdali, M. \& Fennane, M. 2007. Sideritis. In: Fennane, M., Ibn Tattou, M., Ouyahya, A. \& El Oualidi, J. Flore pratique du Maroc 2: 440-448. Trav. Inst. Sci., Sér. Bot. 38. Éditions
Okad, Rabat.

Romo, A. M. 1992. Contribution to the taxonomy and nomenclature of Vascular Plants of Morocco. Bot. J. Linn. Soc. 108: 203-212.

Romo, A. M. 2008. Contribution to the knowledge of rupicolous plant communities in the limestone areas of North Africa. Collect. Bot. (Barcelona) 27: 77-92.

Valdés, B., Redjali, M., Achhal, A., Jury, S. L. \& Montserrat, J.M.(Eds.). 2002. Catalogue des plantes vasculaires du Nord de Maroc, Incluant des clés d'identification, 2 vols. Consejo Superior de Investigaciones Científicas, Madrid.

Weber, H. E., Moravec, J. \& Theurillat, J. P. 2000. International Code of Phytosociological Nomenclature, 3rd edition. $J$. Veg. Sci. 11: 739-768.

Appendix 1. Syntaxonomic synopsis of the syntaxa mentioned in the text.

QUERCO ROBORIS - FAGETEA SYLVATICAE Braun-Blanquet \& Vlieger 1937

+ Querco-Cedretalia atlanticae Barbero, Loisel \& Quézel 1974

Violo munbyanae-Cedrion atlanticae Barbero, Quézel \& Rivas-Martínez 1981

Polysticho setiferi-Prunetum lusitanicae sensu Deil 1984

= Polysticho-Prunetum Barbero, Quézel \& Rivas-Martínez 1981

Primulo acaulis-Betuletum celtibericae Barbero, Quézel \& Rivas-Martínez 1981

= Polysticho setiferi-Prunetum lusitanicae subassoc. betuletosum sensu Deil 1984

CALLUNO VULGARIS - ULICETEA MINORIS Braun-Blanquet \& Tüxen ex Klika \& Hadac 1944

+ Ulicetalia minoris Quantin 1935

Genistion micrantho-anglicae Rivas-Martínez 1979

Genisto anglicae-Ericetum ciliaris Quézel, Barbero, Benabid, Loisel \& Rivas-Martínez 1988 subassoc. pinguiculetosum lusitanicae Romo 2009

ONONIDO - ROSMARINETEA Braun-Blanquet in Braun-Blanquet, Roussine \& Nègre 1952

+ Rosmarinetalia officinalis Braun-Blanquet ex Molinier 1934

Pseudoscabioso-Origanion grosii Quézel Barbero, Benabid, Loisel \& Rivas Martínez. 1988.

Anthyllido polycephalae-Stachydetum fontqueri Quézel, Barbero, Benabid, Loisel \& Rivas Martínez 1988

subassoc. quercetosum rotundifoliae Romo 2009

+ Erinacetalia anthyllidis Quézel 1952

Diantho maroccani-Astragalion maroccani Quézel, Barbero, Benabid, Loisel \& Rivas Martínez 1988 Astragaletum numidico-maroccani Quézel, Barbero, Benabid, Loisel \& Rivas-Martínez 1988

Genistion pseudopilosae-Thymion comosi Benabid 1988

Arenario armerinae-Sideritetum matris-filiae Romo 2009

BETULO PUBESCENTIS - ADENOSTYLETEA ALLIARIAE Braun-Blanquet \& Tüxen ex Braun-Blanquet 1948

+ Cirsietalia flavispinae Quézel 1957

Eryngion variifoliae Quézel 1957

Cephalario maroccanae-Inuletum maletii Romo 2009

Bellis caerulescendis-Heracletum sphondyllii Romo 2009 